\title{
Recent Progress in Alzheimer's Disease Research, Part 2: Genetics and Epidemiology
}

\author{
Morgan Robinson ${ }^{\mathrm{a}}$, Brenda Y. Lee ${ }^{\mathrm{a}}$ and Francis T. Hane $\mathrm{e}^{\mathrm{a}, \mathrm{b}, \mathrm{c}, *}$ \\ ${ }^{a}$ Department of Biology, University of Waterloo, Waterloo, ON, Canada \\ ${ }^{\mathrm{b}}$ Department of Chemistry, Lakehead University, Thunder Bay, ON, Canada \\ ${ }^{\mathrm{c}}$ Thunder Bay Regional Research Institute, Thunder Bay, ON, Canada
}

Accepted 17 January 2017

\begin{abstract}
This is the second part of a three-part review series reviewing the most important advances in Alzheimer's disease (AD) research since 2010. This review covers the latest research on genetics and epidemiology. Epidemiological and genetic studies are revealing important insights into the etiology of, and factors that contribute to $\mathrm{AD}$, as well as areas of priority for research into mechanisms and interventions. The widespread adoption of genome wide association studies has provided compelling evidence of the genetic complexity of $\mathrm{AD}$ with genes associated with such diverse physiological function as immunity and lipid metabolism being implicated in $\mathrm{AD}$ pathogenesis.
\end{abstract}

Keywords: Alzheimer's disease, amyloid precursor protein, APOE, epidemiology, factors, genetics

\section{INTRODUCTION}

This is the second part of a three-part review series covering the most influential advances in Alzheimer's disease (AD) research since 2010. This review covers both its epidemiology and genetics. These two fields have revealed important insights into the complex mechanisms of AD. Uncovering genetic and epidemiological associations and risk factors for disease not only provides a means to understand the factors associated with the initiation of AD but has also led to insights in preventative measures that may delay the onset of AD symptoms. Despite the seemingly causal relationship of certain genes with $\mathrm{AD}$, the complexities of AD should not be underestimated,

\footnotetext{
*Correspondence to: Francis Hane, Department of Biology, University of Waterloo, Oliver rd, Thunder Bay, Waterloo, ON P7B 5E1, Canada. Tel.: +1 807684 6958; E-mail: fthane@ uwaterloo.ca.
}

especially with late onset $\mathrm{AD}$ (LOAD) where numerous interconnected genetic and environmental factors undoubtedly play a role.

Since the identification of the amyloid- $\beta$ protein precursor $(\mathrm{A} \beta \mathrm{PP})$ and the enzymes which cleave A $\beta P P$ ( $\beta$ - and $\gamma$-secretasess) into toxic amyloid- $\beta$ $(A \beta)$, many mutations in key parts of these proteins, including $\mathrm{A} \beta \mathrm{PP}$, Presenilin 1 (PSEN1), and Presenilin 2 (PSEN2), have been implicated in familial or early onset AD (EOAD) [1]. With advances in genomic sequencing and bioinformatics, the identification of other genetic risk factors, such as those involving lipid metabolism and immune function, have also been identified [2-4]. Importantly, AD initiation, age of onset, and disease progression is not entirely governed by genetics: both lifestyle and environmental factors appear to have a significant influence over disease progression. These factors may exert their influence via epigenetic changes to DNA 
and other changes to gene expression. It is these factors that speak most clearly to the complexity of AD pathology.

\section{EPIDEMIOLOGY}

The pathogenesis of AD is multi-faceted and is not limited to one set of simple molecular interactions that occur with age in individuals with genetic predispositions to the disease itself. In the past decade or so, large strides have been made towards a better understanding of the epidemiology of $\mathrm{AD}$, including its occurrence, risk factors, and methods of possible intervention.

\section{Prevalence and incidence}

The Center for Disease Control has estimated that the number of people over the age of 65 will increase from 420 million to almost 1 billion from 2000 to 2030 [5]. This growing geriatric population has placed significant burdens not only on the global economy, but also on the families and caregivers of those who suffer from age-related diseases. Due to the association of $\mathrm{AD}$ with aging, this disease may become an intractable problem on a global scale as the elderly populations continue to rise. Census data has projected that by 2050 , there will be 13.8 million people diagnosed with $\mathrm{AD}$ dementia, with over half above the age of 85 in the United States alone [6]. Currently, there are over 36.5 million people in the world who are affected by dementia, and the majority of these cases are AD-related. Each year, an estimated 5-7 million new cases of AD are recorded in the geriatric population [7-11].

Challenging the common paradigm that dementia rates will continue to increase as the population ages, a very recent study reported that the prevalence of dementia has actually decreased between 2000 and 2012 [12]. In their large and authoritative epidemiological analysis, Langa et al. provided convincing evidence that dementia prevalence has dropped approximately $24 \%$ (11.6\% to $8.8 \%$ ) in just over a decade $(p<0.001)$ [12]. This reduction in dementia prevalence was attributed to the approximate one year increase in education levels among the cohorts [12].

The incidence of $\mathrm{AD}$ increases approximately exponentially with age until an inflection point is reached at the age of 85 [7]. Conflicting results from different studies show that either a decline in incidence is observed after a plateau is reached [13], or that no decline is observed and the plateau continues $[14,15]$. Other studies have shown a decline in the acceleration rate of incidence despite it maintaining an increasing trend with extremely old age $[16,17]$. Interestingly, as incident $\mathrm{AD}$ rates slow with advanced old age, the incidence of vascular dementia decreases, while mixed pathologies show greater incidence with extremely old age [18]. These paradoxical observations may be attributed to differences in datasets, where differences in factors such as sex, educational level, and comorbidity affect incidence and incidence rates [19]. Further studies on a global scale are needed to elucidate the end-stage trends that may be important for predicting the future burden and impact of $\mathrm{AD}$.

\section{Burden and impact}

The current paradigm of AD epidemiology is that as the geriatric population increases along with the incidence of $\mathrm{AD}$, there will be a greater economic burden and societal impact. This paradigm has, however, been undermined by the recent results of Langa et al. which are discussed above [12]. In 2013, there were 84,767 deaths from AD recorded on official death certificates, making $\mathrm{AD}$ the sixth leading cause of death in the United States [20]. It is also likely that mortality due to $\mathrm{AD}$ as reported on death certificates largely underestimates the total number of deaths [21]. Meanwhile, mortality rates from some of the most common non-communicable diseases such as heart disease, stroke, and prostate cancer, have decreased significantly over the years due to advances in healthcare strategies targeting these diseases while deaths from AD continued to rise [20]. These figures underlie the importance of $\mathrm{AD}$ research as this trend will continue without new advances in understanding, treatment, and prevention.

As more individuals are diagnosed with $\mathrm{AD}$, additional funding will be required for formal/informal home care, nursing home expenses, government healthcare expenditures, out-of-pocket expenses from caregivers, and more. Worldwide, the societal costs of dementia were approximately US $\$ 315$ billion in 2005 [7]. In the United States, the total annual cost of dementia is estimated at $\$ 215$ billion in 2010 , and by 2040 the annual cost is expected to double [22].

Since AD is an incurable progressive disease, persistent care and therapy can triple the expenditure of a typical $\mathrm{AD}$ patient compared to one without $\mathrm{AD}$ [23]. 
Preventive strategies that can help delay the onset of AD will significantly help in reducing the global economic burden and societal impact of this disease [10], and closely monitoring $\mathrm{AD}$ risk factors may play a large role in these mitigating strategies.

\section{Factors affecting $A D$ onset}

Although old age is the primary risk factor for $\mathrm{AD}$, there are many other risk and protective factors that may affect the progression or development of AD. These factors can be grouped into two main domains: pre-existing conditions or diseases and lifestyle choices.

Obesity is widely associated with an increased risk of hypertension, stroke, and diabetes. These diseases may be factors that increase the risk of cognitive decline, thereby playing an indirect role in the development of $\mathrm{AD}$. There is growing evidence that suggests that vascular risk factors may increase the risk of incident AD dementia [24]. Overweight patients experience white matter atrophy in their basal ganglia and corona radiata [25]. The mechanism in which obesity causes these reductions in white matter is not clear, although there is a strong correlation between obesity, inflammation, and metabolic disorders such as type 2 diabetes [26, 27].

Type 2 diabetes mellitus (T2DM) is associated with obesity and is often preceded by insulin resistance, followed by improper production of insulin resulting in an insulin deficiency, and therefore a decreased capability to metabolize glucose [28]. T2DM has been shown to increase $\mathrm{AD}$ risk and neurodegeneration [29-31]. In a study reported by Talbot et al., brain insulin resistance in normal to mild cognitively impaired individuals was compared to individuals with AD [32]. Their results demonstrated a steady increase of brain insulin resistance from normal to $\mathrm{AD}$ patients in their hippocampal formations [32]. Combined with other groups' experiments on insulin resistance, these data suggest that brain insulin resistance may be an early and common AD marker, along with IGF-1 resistance and IRS-1 dysfunction [28, 31-33]. Insulin resistance may also be associated with reduced cerebral metabolic rate of glucose in early stages of $\mathrm{AD}[28]$.

Physical activity and diet are important in maintaining general overall health. Regular exercise has been reported to be associated with delayed AD onset and a reduced risk of dementia [7, 34-36]. Walking has been shown to be correlated with greater gray matter volume, which is a protective factor for cognitive decline [34, 37]. Specifically, aerobic exercise training may reverse hippocampal volume loss in late adulthood and therefore improve cognitive function and delay its decline [38]. Daily physical activity has been correlated with a reduced cognitive decline and AD risk [39, 40]. Diet has also been shown have effects on cognition in elderly adults and AD. In particular, the Mediterranean diet and diets high in seafood have received a large amount of attention for being protective [41, 42], while evidence suggests that diets high in sugar and saturated fats have detrimental effects on cognition [43].

Mentally demanding activities may act as a protective factor against the onset and progression of $\mathrm{AD}$ $[7,44]$. Andel et al. examined the risk of AD in association with the complexity of work performed over a long period of time [45]. Their findings suggest that mentally-demanding tasks of greater complexity may reduce the risk of $\mathrm{AD}$ [45]. These results and others have led to the formation of the cognitive reserve hypothesis, which posits that excess dendritic connections provide a reserve so that executive function is still retained with increasing cerebral atrophy [46].

Stress is a factor in the development of many chronic conditions including $\mathrm{AD}$, and levels of glucocorticoids are often correlated with cognitive deficits and $\mathrm{AD}$ pathology $[47,48]$. The relationship between stress and the immune system may play an important role in explaining the link between stress and $\mathrm{AD}$ [49]. Whether stress contributes to AD pathology or is a result of AD is not entirely clear; it is possible though, that AD pathology and stress act in a positive feedback loop, both exacerbating the other. Psychological well-being is important for healthy aging. Poor psychological well-being, as measured by self-reported vigor and activity, has been associated with greater AD pathology in subjects with mild cognitive impairment, compared to controls, as measured using PET imaging [50]. Similar results have been reported in association with a sense of purpose in life, where postmortem analysis of 246 older adults revealed higher levels of purpose reduced $\mathrm{AD}$ pathology and cognition [51].

\section{GENETICS}

The major $\mathrm{AD}$ genes that were first associated with AD greatly support the merit of the traditional amyloid cascade hypothesis (albeit a more complex and nuanced consensus has emerged since this 
hypothesis was first proposed). The genes A $\beta P P$, PSEN1, and PSEN2 all directly affect amyloid production or cleavage. Following the discovery of these initial genetic associations, it was discovered that certain mutations in these genes are almost certainly responsible for EOAD, caused by an increase in the aggregation of toxic amyloid species [1, 52-54]. The pathology of LOAD, however, appears to be much more complicated; the hallmark pathologies of LOAD appears much later, progress more slowly, and all without genetic mutations in A $\beta P P$, PSEN1, and PSEN2. It has therefore been a long-standing question of whether or not the same pathologies underlie these seemingly distinct manifestations of AD considering the very similar pathologies, albeit much slower rate of progression. Overproduction and/or impaired clearance of $A \beta$ appear in both LOAD and EOAD, although the specific mechanisms may differ, they remain elusive. The next significant gene identified is associated with LOAD and encodes a regulatory protein called apolipoprotein E (APOE) involved in lipid metabolism and trafficking. With no obvious direct connection to the amyloid pathway this further obscured the connection between early and late onset AD. Identification of now $20+$ genes associated with LOAD is revealing insights into the complex nature of the etiology of LOAD which differs from early onset $\mathrm{AD}$.

The lack of consensus surrounding AD etiology is highlighted by the complexity of the genetics factors implicated in $\mathrm{AD}$, with a large collection of genes that affect disease progression and risk. Figure 1 contains a summary of genes that are implicated in AD pathology as a function of their risk and population frequency. Genome wide association studies (GWAS) have been used to identify alleles associated with a particular trait or disease. GWAS do not require sequencing large sets of genomes, but rely on analyzing single nucleotide polymorphisms (SNPs) at a large number of loci $\left(10^{6}-10^{7}\right)$ within the genome [4]. Confidence in the association between the allele and disease has a threshold that may not detect all alleles; these rare alleles must be found by direct sequencing of known associated genes in large populations [4].

\section{Genome wide association studies}

GWAS of human nonagenarians (90-99 years of age) and centenarians (over 100 years of age) have revealed genetic signatures with varying predictive power for exceptionally long life, with three different signatures corresponding to three different lifespans [55]. Only one particular SNP in APOE/TOMM40 reached irrefutable genome-wide significance while 112 SNPs were associated with, but did not meet, the strict threshold for genome-wide significance [55]. Taken together, these data suggest that genetic predisposition for exceptional longevity is a result of the joint effect of sets of SNPs and not a small selection of specific SNPs, that has similarly been observed with other complex phenotypes [55].

Early GWAS were unable to find new loci involved in LOAD with no locus other than APOE regions reaching significance; this is likely due to the limited power of small GWAS [4]. Two larger studies published in 2009 by Lambert et al. and Harold et al. identified new loci associated with $A D$ at CLU, CR1, and PICALM genes that encode apolipoprotein $\mathrm{J}$, complement receptor type 1 (a protein involved in innate immunity), and a lipid binding protein involved in endocytosis and vesicle formation, respectively [56, 57]. To confirm this finding in an independent sample, and possibly find new loci associated with AD, Seshadri et al. performed a GWAS consisting of three stages on more than 35,000 individuals [58]. They found a significant association of CLU and PICALM as well as identified new loci near BIN1 and EXOC3L2/BLOC1S3/MARK4 [58]. Further verification of CR1, CLU, and PICALM association with LOAD was performed in a metaanalysis association study of AD [59]. Separate analysis in the context of APOE genotypes, accounting for APOE $\varepsilon 4$ allele, resulted in a reduction of the association with PICALM, suggesting an interaction between PICALM and APOE genotypes [59]. A three-phase GWAS was performed by the Alzheimer's Disease Genetics Consortium (ADGC) using both joint analysis and meta-analysis; the ADGC identified eight genes thought to have genome wide significance, four of which had been previously associated with LOAD (CR1, CLU, BIN1, and PICALM), and four representing novel associations MS4A4A, CD2AP, EPHA1, and CD33: genes involved in immune function, cytoskeletonmembrane trafficking, intracellular signaling, and $A \beta$ clearance [60]. These studies emphasize the complex nature of genetic risk factors involved in $\mathrm{AD}$.

GWAS of 549 AD and 544 non-AD Caribbean Hispanic individuals identified twenty-three associations, five of which were verified in an independent cohort; genetic associations with previously known CLU, PICALM, and BIN1 were also observed [61]. 


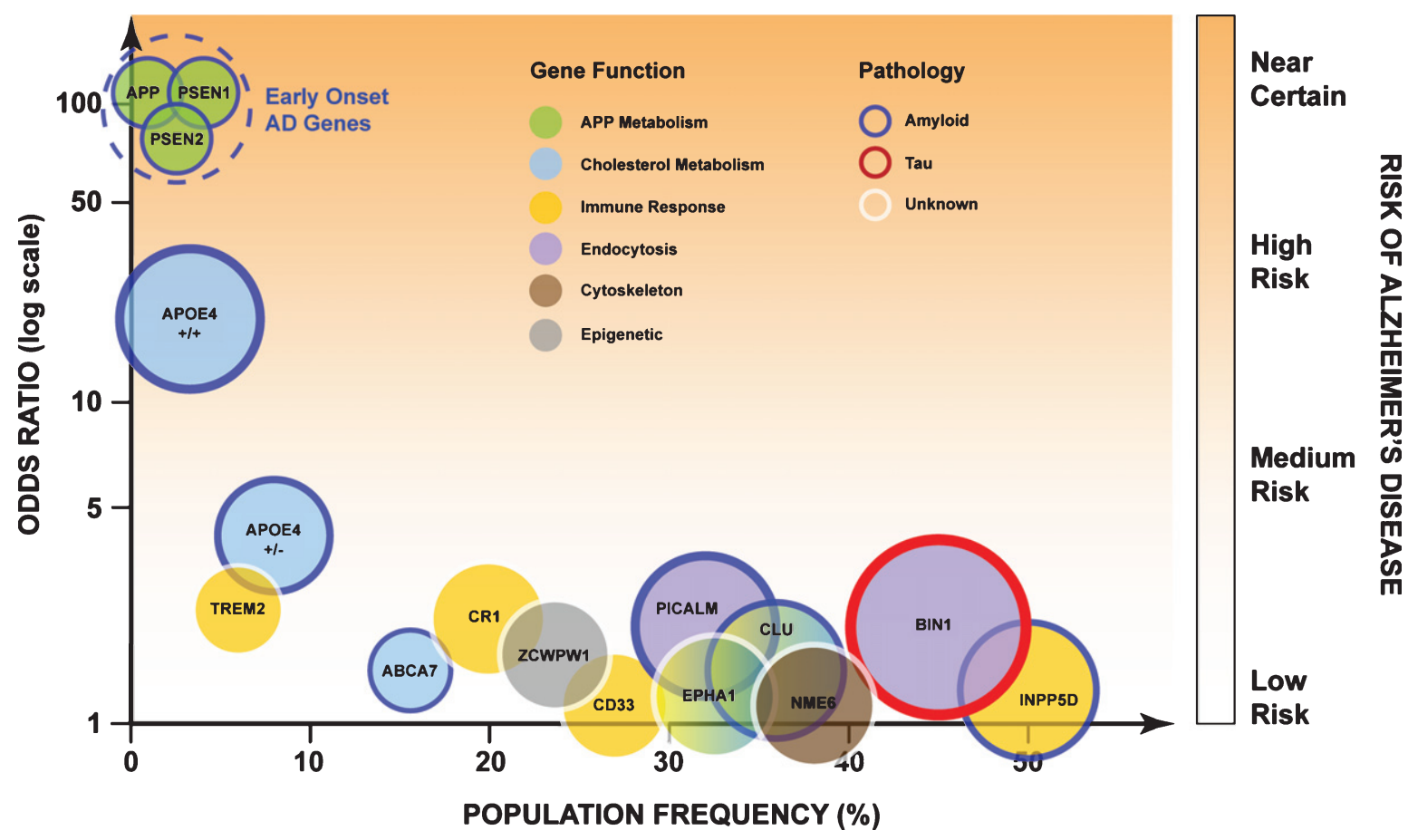

Fig. 1. Genetic risk factors for $\mathrm{AD}$ and their general role in physiological function. High risk genes are associated with increased severity of the disease and earlier age of onset, with low risk genetic factors age of onset is delayed and disease severity is less. The area of each circle is proportional to each genes' population attributable fraction (PAF). "Larger" genes have a greater influence of AD within the population. Figure adapted with permission [64]. See online version for colour figure.

Similar GWAS in African Americans (513 AD cases and 496 controls - 2.5 million SNPs) resulted in associations observed with SNPs in CLU, PICALM, BIN1, EPHA1, MS4A4A, ABCA7, and CD33 as well as in the region of the APOE gene [62]. In addition, some evidence for associations with SNPs in the vicinity of previously unidentified genes were found that are not observed in white populations including: PROX1, P4HA3, ZC3H3, TMTC1, and ENOX; with the latter three associations appearing after adjusting for APOE $\varepsilon 4$ alleles [62].

A large meta-analysis of GWAS published in 2013 involving a total of 74,046 subjects identified eleven new loci associated with $\mathrm{AD}$, while an additional nine previously known loci had a significant association, including: APOE, BIN1, CLU, CR1, and PICALM among others [63]. Of the eleven new genes found to be associated with AD, SORL1 and CASS4 may be involved in the A $\beta P P$ pathway; CASS4 and FERMT2 the tau pathway; HLA-DRB5-DRB1, INPP5D, and MEF2C in immune function and inflammation; and SORL1 may be involved in lipid transport and endocytosis [63]. This study reinforces the complex nature of $\mathrm{AD}$ by identifying 20 genetic loci that affect risk, age of onset and disease severity. Additional comprehensive reviews of GWAS in AD are provided in references [2, 4].

\section{$A \beta P P$ and PSEN}

The production of $A \beta$ is dependent on enzymatic processing by $\beta$-site $A \beta P P$ cleaving enzyme 1 (BACE1). Mutations in the coding region of A $\beta P P$ near or at the BACE1 cleavage site can increase toxic $A \beta$ production, while mutations in the $A \beta$ region of A $\beta P P$ may result in accelerated aggregation. A GWAS of 1,795 Icelanders resulted in the identification of a coding mutation (A673T) adjacent to the BACE1 cleavage site which was then shown to reduce the formation of $\mathrm{A} \beta$ by $40 \%$ in vitro; in addition this mutation not only provides protection from $\mathrm{AD}$ but also protects against cognitive decline in the elderly [65].

$\gamma$-secretase is a critical enzyme that cleaves a variety of type I membrane proteins including A $\beta P P$ and Notch proteins. Inactivation of $\gamma$-secretase in mice causes similar skin abscesses as those found in human acne inversa (AI), an inflammatory disease of the hair 
follicle. Genome wide linkage studies and haplotype analysis of genetic data from six Chinese families that display familial AI revealed several different mutations in the genes encoding various components of the $\gamma$-secretase protein complex (including: PSEN1, presenilin enhancer 2, and nicastrin) [66]. As mutations in PSEN1 and PSEN2 are known to cause familial AD and other dementias, AI may be a related allelic disorder; however, of the 15 individuals who were over age 50, none displayed symptoms of AD or dementia [66]. Further studies on these individuals with AI that contain PSEN1 mutations are necessary to establish a link between AI caused by mutations in PSEN1 and $\mathrm{AD}$.

Autophagy is critical for the removal of aggregated protein species that may accumulate within cells, in particular $A \beta$. Hee et al. have reported that lysosomal dependent proteolysis involved in autophagy is dependent on the PSEN1 subunit of $\gamma$-secretase while non-lysosome proteolysis is not [67]. They show that PSEN1 knockout prevents activation of proteases involved in the degradation of the autophagic lysosomes as it appears to act as a chaperone for v-ATPase V0a1 subunit within the ER. In a similar way, mutations of the gene encoding PSEN1 responsible for familiar AD also cause cells to exhibit deficiencies in autophagy although to a lesser extent than knockout cells [67]. The $\gamma$-secretase complex plays a critical role in the processing of $A \beta P P$ into $A \beta$ fragments via its major catalytic component, PSEN1, which also plays a critical role in autophagy. Recent work shows that $\gamma$-secretase inhibitors do not impact autophagy which implies the role PSEN1 plays in lysosome proteolysis is independent of $\gamma$-secretase [68]. This work highlights the importance of autophagy in accelerating disease progression as seen in presenilinbased FAD and that autophagy is not dependent on $\gamma$-secretase but the multifunctional subunit PSEN1.

Sequencing of a few major known AD genes A $\beta P P$, PSEN1, PSEN2, microtubule associated protein tau (MAPT), and progranulin (GRN) in 439 families with a history of LOAD identified 33 nonsense, missense and splice-site sequence variants within 60 families $(13.7 \%)$, a total of 1,806 cases [69]. Of these cases, 28 were rare non-synonymous variants, eight pathogenic or likely pathogenic variants in A $\beta P P$, MAPT, PSEN1, and GRN, but not PSEN2, three of which had not been previously identified [69]. MAPT and GRN mutations in this sample may represent misdiagnosis of, or overlap with, AD.

The major pathogenic component of the A $\beta P P$ is believed to be $A \beta$; however, during $\mathrm{A} \beta \mathrm{PP}$ cleavage, two other fragments are also produced, the large extracellular fragment $\mathrm{SAPP} \beta$ and the intracellular fragment, the role of neither are understood. Transcriptional profiling has revealed that transthyretin and Klotho gene expression is dependent on A $\beta P P$ [70]. The sAPP $\beta$ fragment was shown to restore TTR and Klotho gene expression in AßPP and A $\beta P P-l i k e$ protein 2 double knockout mice; however, this had no effect on the lethal and neuromuscular with the mouse model [70]. These results suggest that SAPP $\beta$ regulates gene expression of TTR and Klotho but that A $\beta P P$ and its cleavage products serve other critical roles in normal physiology.

\section{Apolipoproteins}

The APOE $\varepsilon 4$ allele is a major genetic risk factor for $\mathrm{AD}$, causing earlier onset and accelerating symptoms. These symptoms correlate pathologically with increased cortical amyloid deposition as observed with greater binding by ${ }^{11} \mathrm{C}$ labelled Pittsburgh Compound $\mathrm{B}(\mathrm{PiB})$ imaging agent. APOE was the first major known risk factor for LOAD with $A \beta P P$, PSEN1, and PSEN2 being responsible for familial or EOAD. Along with AD, APOE has been implicated in atherosclerosis, an inflammatory condition of the arteries, as well as hypertension [71]. The link between disrupted lipid homeostasis-transport, metabolism, and signaling-and various diseases including inflammatory, neurodegenerative, and cardiovascular disease is unclear. It is likely that the precise mechanisms of disease differ between different APOE carrier types with AD and that these mechanisms could compound, or act synergistically with the historically central $A \beta$ pathology.

The APOE lipoprotein is the primary modulator of cholesterol in the brain and is strongly associated with $\mathrm{AD}$ pathology due to its complex role in lipid and protein homeostasis [72]. To further understand the role of various APOE genotypes in preclinical measures of $\mathrm{AD}$ in vivo, cerebral amyloid imaging of $\mathrm{PiB}$ and cerebrospinal fluid (CSF) assays of $A \beta$ and tau protein have been performed [73]. PiB binding increased in an age-dependent manner and increased further with gene dosing of APOE $\varepsilon 4$, CSF levels of $A \beta_{42}$ were decreased with age and furthermore with APOE $\varepsilon 4$; APOE $\varepsilon 2$ showed no binding of $\mathrm{PiB}$ and increased $\mathrm{A} \beta_{42}$ in CSF [73]. Markers of tau pathology were not associated with APOE genotype suggesting that APOE gene does not affect tau pathology but acts on $A \beta$ pathology [73]. 
Molecular and imaging biomarkers of cerebral $\mathrm{A} \beta$ in humans has been found to vary according to the isoform of APOE suggesting differential effects of APOE alleles on $A \beta$ homeostasis [73]. The $A \beta$ concentration in human subjects with normal cognitive function over 70 years, as measured by CSF and imaging with $\mathrm{PiB}$, was highest in $\varepsilon 4$ and lowest in $\varepsilon 2$ isoforms, with only one copy of the most common isoform $(\varepsilon 3)$ bringing levels of PiB binding to half that of $\varepsilon 4$ [73, 74]. In vivo reduction of $A \beta$ metabolism and clearance, was observed in microdialysis experiments with a mouse model of $A \beta$ amyloidosis that also expressed human APOE isoforms, while the levels of $A \beta$ synthesis remained unchanged [74]. This suggests that APOE plays a role in amyloid metabolism and clearance, but not synthesis, and that upregulation of clearance mechanisms may be an effective strategy for preventing $\mathrm{AD}$, particularly in APOE $\varepsilon 4$ positive individuals.

APOE $\varepsilon 4$ is the largest known genetic risk factor for LOAD as compared to APOE $\varepsilon 3$ [1]. Transgenic mice modified to have increased $A \beta$ load and homozygous for either isoform of APOE $(\varepsilon 3 / \varepsilon 3$ and $\varepsilon 4 / \varepsilon 4)$ were compared to mice with haploinsufficiency in either isoform ( $\varepsilon 3 /-$ and $\varepsilon 4 /-)$ [75]. Both strains of haploinsufficient mice showed reductions in expression of APOE resulting in reduced $A \beta$ plaque deposition and microglial activation [75], suggesting that APOE alleles in general increase plaque deposition and $A \beta$ pathology.

Several GWAS have identified an association between APOE and translocase of outer mitochondrial membrane 40 homolog (TOMM40) and APOC1 in a region of linkage disequilibrium. Phylogenetic analysis of all polymorphisms including structural and SNPs has revealed a polymorphic poly-T variant in TOMM40 that is an early predictor of AD in patients with APOE $\varepsilon 3 / \varepsilon 4$ genotype, with the longer polymorph causing an earlier onset by an average of 7 years $(70.5 \pm 1.2$ years versus $77.6 \pm 2.1$ years) [76]. The TOMM40 encodes a subunit of the outer mitochondrial pore protein; as $A \beta$ is known to accumulate in the mitochondria and cause dysfunction there appears to a physiological basis for these observations.

Carriers of the APOE $\varepsilon 4$ allele had decreased PiB binding with increased exercise, while sedentary behavior had the opposite effect [77] suggesting that exercise reduces amyloid deposition within the brain and is especially beneficial for APOE $\varepsilon 4$ carriers, potentially reducing risk or delaying onset of $\mathrm{AD}$. Inflammation in $\mathrm{AD}$ is a well-established phenomenon; importantly inflammation is partially regulated by lipid mediators and lipid membrane changes. Reduced apolipoprotein A-I (APOA-I) and plasma high density lipoprotein levels are found in AD patients, leaving to reason whether an increase in either one of these molecules would be beneficial. Indeed, a triple transgenic mice model with elevated AßPP, PSEN1, and APOA-I expression was found to have protection from cognitive deficits observed in mice with AßPP and PSEN1 overexpression alone [78]. This correlates with doubling of plasma HDL levels in APP/PRES1/APOA-I mice compared to A $\beta P P / P R E S 1$ mice and a marked reduction in microglial activation, neuroinflammation and cerebral amyloid angiopathy without any change in $A \beta$ levels in the brain [78]. Reduction in neuroinflammation by increasing HDL levels and/or APOA-I may be a strategy for preventing or slowing AD.

CLU, also known as apolipoprotein $\mathrm{J}$, has been identified in multiple GWAS of AD, in particular, the $\mathrm{C}$ allele SNP increases chances of developing AD by 1.16 times, with approximately $37 \%$ of Caucasians carrying two copies of CLU-C this an important gene of interest [79]. Braskie et al. tested whether white matter integrity is affected in CLU-C carriers at early life stages using diffusion tensor imaging. They observed decreased fractional anisotropy, a measure of white matter integrity in young adults in brain areas associated with neurodegeneration seen in AD [79].

\section{Lipid homeostasis and immune dysfunction}

In addition to the associations of apolipoproteins with $\mathrm{AD}$, other genes important for lipid homeostasis and immune function have also been implicated in AD. Reactive oxygen species (ROS) signaling is critical in autophagy, the lysosomal dependent degradation of aggregated protein products in the body, such as $A \beta$. Knockdown of the ROS detoxification pathway involving SOD1 resulted in increased ROS and subsequently autophagy in human neuroblastoma cells, both ROS production and autophagy were reduced when treated with antioxidants [80]. Gene expression data suggests that there is an upregulation of autophagy in brain regions associated with pathology in AD patients. This is in contrast to down regulation observed in normal aging of non-AD individuals [80]. Increased autophagy in AD patients is likely to compensate for increased misfolded $A \beta$ protein in a ROS independent manner [80]. Changes in autophagy expression levels are likely induced by $A \beta$, both by ROS production and transcriptional 
mechanisms, as $\mathrm{A} \beta$ initiates autophagy and inhibits lysosomal degradation even in the presence of antioxidants [80].

Cholesterol metabolism, inflammation, and innate immunity have all been correlated with LOAD, both in physiological and epidemiological studies; however, whether these correlations are causal or consequential is unclear. Using two GWAS datasets [56, 57], Jones et al. provided evidence that the genes involved in sterol and lipid metabolism, and immune response are likely involved in the etiology of LOAD [3]. Interestingly, gene functional categories from gene ontology and KEGG databases involved in sterol, lipid and immune related processes were found in excess but no gene categories directly related to $A \beta P P, A \beta P P$ processing, or $A \beta$ were found to contain significant SNPs for either dataset. This is contrary to GWAS of EOAD which found associations between genes in the $A \beta$ pathway [3]. This suggests a stark difference in the etiology of EOAD and LOAD, that although $A \beta$ pathology is central the mechanisms of each disease differ.

The genetic risk factor CD33 identified by GWAS is a transmembrane protein involved in innate immunity but whose function in the brain is largely unknown [60, 62]. In one recent study, Griciuc et al. reported a 2-fold increase in the expression of $\mathrm{CD} 33$ in brain microglia of $\mathrm{AD}$ patients as measured postmortem in $25 \mathrm{AD}$ patients and 15 age-matched controls [81]. A minor protective allele of CD33 was found not to involve changes in mRNA levels despite lower protein expression suggesting this allele influences translation or protein stability [81]. Griciuc et al. also demonstrated that CD33 inhibits the uptake and clearance of $\mathrm{A} \beta$ by microglial cells in vitro and in vivo using a transgenic $\mathrm{AD}$ model combined with double knockout of CD33 (APP/PSEN1/CD33-/-) [81]. This observation suggests a possible role for $\mathrm{CD} 33$ in $\mathrm{A} \beta$ pathology, and perhaps intervention.

Triggering receptor expressed on myeloid cells 2 protein (TREM2) has been associated with a recessive form of early onset dementia; to explore the link in the context of $\mathrm{AD}$ specific dementia, further assessment by Guerreiro et al. has found 22 different low frequency TREM2 alleles in 1,092 AD patients but only 5 different alleles in 1,107 controls [82]. Highly significant association, from the meta-analysis of three GWAS, of the TREM2 variant R47H with AD was found and then validated by sequencing an additional 1,887 AD patients and 4,061 controls [82]. The variant $\mathrm{R} 47 \mathrm{H}$ was found to significantly increase risk of $\mathrm{AD}$ in an association study of 2,261 Icelanders.
Furthermore, non-AD individuals with this mutation between 80 and 100 years had poorer cognitive function than controls [83]. TREM2 is involved in the neuroimmune system via its anti-inflammatory role in the brain and it is likely that the $\mathrm{R} 47 \mathrm{H}$ mutation interferes with this function to predispose individuals to $\mathrm{AD}$.

Hyperphosphorylated MAPT, a definitive marker of tauopathies and observed in $\mathrm{AD}$, is promoted by neuroinflammation which is activated and sustained by microglial cells. Non-Tg mice treated with immunoreactive lipopolysaccharide lacking in microglial specific fractalkine receptor (CX3CR1) were shown to be more susceptible to hyperphosphorylation of MAPT than control mice dependent on toll-like receptor 4 and interleukin-1 receptors [84]. This same trend was observed in $\mathrm{Tg}$ mice with humanized MAPT, in addition to hyperphosphorylation was increased levels of active p38 MAPT [84].

\section{Other genetic factors in memory and neurodegeneration}

The zinc transporter-3 (ZnT3) protein controls synaptic zinc levels; ZnT3 double KO mice express cognitive deficits phenotypically similar to AD [85]. ZnT3 double KO mice exhibit age related cognitive deficits in learning and memory beginning at 6 months due to reductions in hippocampal proteins involved in learning and memory as determined by western blot [85]. In $\mathrm{AD}$ extracellular $\mathrm{A} \beta$ sequesters and traps $\mathrm{Zn}$ and $\mathrm{ZnT} 3$ levels are reduced in the brain, resulting in decreased trans-synaptic zinc [85]. These similarities make ZnT3 double KO mice a possible candidate as a phenotypic model of AD.

In a rare example of a genetic factor increasing cognitive function, lentiviral vector that causes overexpression of protein kinase $\mathrm{M} \zeta(\mathrm{PKM} \zeta)$ in the neocortex has been shown to enhance long term memory while the use of a disrupted dominant negative $\operatorname{PKM} \zeta$ was observed to disrupt memory [86].

Striatal-enriched phosphatase (STEP) regulates internalization of NMDA and NMDA ligands, of which include $A \beta$, this NMDA mediated internalization of $A \beta$ may be an important component of synaptic dysfunction observed in AD [87]. When STEP activity was reduced in a triple transgenic mouse model of $\mathrm{AD}\left(3 \mathrm{xTg}-\mathrm{AD} / \mathrm{STEP}^{-/-}\right)$, a reversal of cognitive and cellular deficits compared to the $3 \times$ Tg-AD mice with regular STEP expression was observed, despite having the same levels of $A \beta$ and phosphorylated tau [87]. 


\section{Gene expression and epigenetics}

MicroRNA (miRNA) is a small non-coding nucleic acid post-transcriptional regulator that can reduce protein translation by binding to the complementary mRNA sequence. The first profiling of miRNAs in the $\mathrm{AD}$ brain was recently performed showing the miRNA levels in the parietal lobe cortex in AD patients can positively or negatively correlate with their target mRNA levels highlighting, again, the complexity of the route from gene to protein product [88]. Changes in miRNA-mRNA interactions were observed in $\mathrm{AD}$ versus control; how these changes affect $\mathrm{AD}$ progression is unknown and further studies are needed to elucidate the role of miRNA in $\mathrm{AD}$ [88].

Protein production is largely regulated by chemical modifications to the genome; this system is referred to as the epigenome. Histone acetylation destabilizes electrostatic affinity between histones and DNA making chromatin easier to access, promoting transcription. This epigenetic process of gene expression is critical to learning and memory. Histone phosphorylation has been directly observed in brain tissue from AD patients [89] and a decrease in histone acetylation has been observed in animal models of $\mathrm{AD}$ due to increased histone deacetylase (HDAC)-2 [90]. A mouse model denoted CK-p25 produces a truncated version of an important protein to produce a cyclin-dependent kinase 5 (CDK5) response resulting in increased HDAC2 [90]. This downregulates a large number of genes and receptors involved in learning, memory, and synaptic plasticity such as glutamate receptors subunits [90]. Blocking these epigenetic cascades with short-hairpin RNAs (shRNA) directed against HDAC2 were used to show HDAC2 dependent regulation of the genes of interest in CK-p25 mice with the shRNAs recovering or increasing basal protein expression compared to controls [90].

DNA methylation is a potent form of epigenetic regulation that has been observed to be altered in AD subjects [91, 92]. Epigenomic studies are revealing common sites of methylation that occur in $\mathrm{AD}$, including at genomic sites ABCA7 and BIN1 regions (which have been identified previously in genomic studies and validated associations by measuring RNA expression of nearby genes, including: ANK1, CDH23, DP2A, RPL13, SERPINF1 and 2 [91]. ANK1 has been identified independently in an epigenome wide association study as a gene whose methylation is associated with cortical deregulation in the context of AD [93]. Several loci were found to be associated with AD as discussed in previous sections, a role for DNA methylation at these sites in $\mathrm{AD}$ was recently found; the loci are as follows: SORL1, ABCA7, HLA-DRB5, SLC24A4, and BIN1 [94]. There remains much uncertainty as to the complete role for DNA methylation and other forms of epigenetic regulation to changes in gene expression associated and caused by AD. The connections between regulation and the resulting molecular structures are only just beginning to be probed.

Gene expression is important as it controls molecular pathways mediated through the function of translated proteins; these connections between genome regulation and higher-order molecular pathways can be explored through a variety of approaches. In a study using an integrated systems approach comparing molecular network structures of 1,647 postmortem brains of LOAD patients and controls, a significant amount of reconfigurations in immune- and microglia-specific pathways were observed, specifically genes involved in pathogen phagocytosis [95]. Genetic and epigenetic regulation of these genetic nodes may be in part responsible for the differences observed between LOAD and control subjects.

Inflammation and immunity play a key role in health and aging, with dysfunction resulting in cardiovascular, neurodegenerative and auto immune diseases. Many genes involved in immunity have also been associated with AD. A recent expression quantitative trait locus (eQTL) study, which aimed to identify regions of DNA with variations that contribute to a particular trait, have revealed interesting insights comparing gene expression in leukocytes derived from myeloid (monocytes) and lymphoid (T cells) origin [96]. Correlations in genes associated with AD and QTLs in monocytes were found, while T cell QTLs were identified that correspond to genes associated with auto-immunity [96]. This polarization between cells of the immune system highlights the importance of cell-type specific gene expression and genetic risk factors in disease. Moreover, as the myeloid derived cells are most commonly associated with innate immunity as opposed to adaptive immunity, this study suggests that neurodegeneration and brain aging is more related to dysfunction in innate rather than adaptive immunity.

Transcriptional and genetic postmortem analysis of the prefrontal cortex from 269 subjects without neurological disorder across most of the human lifespan, from fetal development to old age, reveals temporal changes in gene expression that globally 
appear to be independent of genotype [97]. Despite thousands of genetic associations of SNPs with gene expression, these large genetic differences between individuals result in no change to their transcriptional profiles, and molecular structure, in the prefrontal cortex between individuals of similar age [97]. These results indicate the importance of highly regulated pathways that produce age-dependent, higher-order molecular structures within the brain despite huge genetic variations in the population [97].

\section{CONCLUSION}

Key themes have emerged in both genetic and epidemiological studies in $\mathrm{AD}$ that may continue to support a central pathology surrounding amyloidosis via $A \beta$ production (from $A \beta P P$ processing) and accumulation (from impaired metabolism and clearance). The $A \beta$ pathway is than further influenced by other genetic and epidemiological risk factors that have been identified and described in this review including tau neurotoxicity, lipid/protein homeostasis, innate immunity, and lifestyle choices. As lipid homeostasis (trafficking and metabolism) plays a critical role in innate immunity via lipid mediators and changes in cell membrane composition it should not be surprising to see these common themes emerge, especially considering the pathology of $\mathrm{AD}$ contains microglial activation and features of neuroinflammation. The observations reported in this review could alternatively support a hypothesis of AD where immunological dysfunction (including dysfunction as a result of impaired lipid trafficking and metabolism) is the primary insult that results in the overproduction and accumulation of $A \beta$ the associated pathology along with hyperphosphorylated tau and oxidative stress in parallel.

Epidemiological studies have demonstrated that healthy active lifestyles with moderate exercise and carefully maintained mental health, may serve to delay the onset of LOAD. Meanwhile, genetic studies have identified novel targets for the development of pharmaceuticals which modulate the influence of low risk genetic factors.

\section{ACKNOWLEDGMENTS}

FH wishes to acknowledge the BrightFocus Foundation and its generous donors for support of this work.
Authors' disclosures available online (http://j-alz. com/manuscript-disclosures/16-1149r2).

\section{REFERENCES}

[1] Tanzi RE, Bertram L (2005) Twenty years of the Alzheimer's disease amyloid hypothesis: A genetic perspective. Cell 120, 545-555.

[2] Medway C, Morgan K (2014) Review: The genetics of Alzheimer's disease; putting flesh on the bones. Neuropathol Appl Neurobiol 40, 97-105.

[3] Jones L, Holmans PA, Hamshere ML, Harold D, Moskvina V, Ivanov D, Pocklington A, Abraham R, Hollingworth P, Sims R, Gerrish A, Pahwa JS, Jones N, Stretton A, Morgan AR, Lovestone S, Powell J, Proitsi P, Lupton MK, Brayne C, Rubinsztein DC, Gill M, Lawlor B, Lynch A, Morgan K, Brown KS, Passmore PA, Craig D, Mcguinness B, Todd S, Holmes C, Mann D, Smith AD, Love S, Kehoe PG, Mead S, Fox N, Rossor M, Collinge J, Maier W, Jessen F, Schürmann B, van den Bussche H, Heuser I, Peters O, Kornhuber J, Wiltfang J, Dichgans M, Frölich L, Harald H, Hüll M, Rujescu D, Goate AM, Kauwe JSK, Cruchaga C, Nowotny P, Morris JC, Mayo K, Livingston G, Bass NJ, Gurling H, Mcquillin A, Gwilliam R, Deloukas P, Al-Chalabi A, Shaw CE, Singleton AB, Guerreiro R, Mühleisen TW, Nöthen MM, Moebus S, Jöckel KH, Klopp N, Wichmann HE, Rüther E, Carrasquillo MM, Pankratz VS, Younkin SG, Hardy J, O’Donovan MC, Owen MJ, Williams J (2010) Genetic evidence implicates the immune system and cholesterol metabolism in the aetiology of Alzheimer's disease. PLoS One 5, e13950.

[4] Tosto G, Reitz C (2013) Genome-wide association studies in Alzheimer's disease: A review. Curr Neurol Neurosci Rep 13, 381 .

[5] Centers for Disease Control and Prevention (2003) Public health and aging: Trends in aging-United States and worldwide. JAMA 289, 1371-1373.

[6] Hebert LE, Weuve J, Scherr PA, Evans DA (2013) Alzheimer disease in the United States (2010-2050) estimated using the 2010 census. Neurology 80, 1778-1783.

[7] Qiu C, Kivipelto M, von Strauss E (2009) Epidemiology of Alzheimer's disease: Occurrence, determinants, and strategies toward intervention. Dialogues Clin Neurosci 11, 111-128.

[8] Ferri CP, Prince M, Brayne C, Brodaty H, Fratiglioni L, Ganguli M, Hall K, Hasegawa K, Hendrie H, Huang Y, Jorm A, Mathers C, Menezes PR, Rimmer E, Scazufca M (2005) Global prevalence of dementia: A Delphi consensus study. Lancet 366, 2112-2117.

[9] Wimo A, Winblad B, Aguero-Torres H, von Strauss E (2003) The magnitude of dementia occurrence in the world. Alzheimer Dis Assoc Disord 17, 63-67.

[10] Brookmeyer R, Johnson E, Ziegler-Graham K, Arrighi HM (2007) Forecasting the global burden of Alzheimer's disease. Alzheimers Dement 3, 186-191.

[11] Sosa-Ortiz AL, Acosta-Castillo I, Prince MJ (2012) Epidemiology of dementias and Alzheimer's disease. Arch Med Res 43, 600-608.

[12] Langa KM, Larson EB, Crimmins E, Faul JD, Levine DA, Kabeto MU, Weir DR (2017) A Comparison of the Prevalence of Dementia in the United States in 2000 and 2012. JAMA Intern Med 177, 51-58.

[13] Miech RA, Breitner JCS, Zandi PP, Khachaturian AS, Anthony JC, Mayer L (2002) Incidence of AD may decline 
in the early 90s for men, later for women: The Cache County study. Neurology 58, 209-218.

[14] Fratiglioni L, Launer LJ, Andersen K, Breteler MM, Copeland JR, Dartigues JF, Lobo A, Martinez-Lage J, Soininen H, Hofman A (2000) Incidence of dementia and major subtypes in Europe: A collaborative study of population-based cohorts. Neurologic Diseases in the Elderly Research Group. Neurology 54, S10-S15.

[15] Matthews F, Brayne C (2005) The incidence of dementia in England and Wales: Findings from the five identical sites of the MRC CFA Study. PLoS Med 2, e193.

[16] Gao S, Hendrie HC, Hall KS, Hui S (1998) The relationships between age, sex, and the incidence of dementia and Alzheimer disease: A meta-analysis. Arch Gen Psychiatry 55, 809-815.

[17] Hall CB, Verghese J, Sliwinski M, Chen Z, Katz M, Derby C, Lipton RB (2005) Dementia incidence may increase more slowly after age 90: Results from the Bronx Aging Study. Neurology 65, 882-886.

[18] Jellinger KA, Attems J (2010) Prevalence of dementia disorders in the oldest-old: An autopsy study. Acta Neuropathol 119, 421-433.

[19] Kukull WA, Higdon R, Bowen JD, McCormick WC, Teri L, Schellenberg GD, van Belle G, Jolley L, Larson EB (2002) Dementia and Alzheimer disease incidence: A prospective cohort study. Arch Neurol 59, 1737-1746.

[20] Alzheimer's Association (2015) Alzheimer's disease facts and figures. Alzheimers Dement 11, 332-384.

[21] James BD, Leurgans SE, Hebert LE, Scherr PA, Yaffe K, Bennett DA (2014) Contribution of Alzheimer disease to mortality in the United States. Neurology 82, 1045-1050.

[22] Hurd MD, Martorell P, Delavande A, Mullen KJ, Langa KM (2013) Monetary costs of dementia in the United States. $N$ Engl J Med 368, 1326-1334.

[23] Wimo A, Winblad B, Jonsson L (2007) An estimate of the total worldwide societal costs of dementia in 2005 . Alzheimers Dement 3, 81-91.

[24] Li J, Wang YJ, Zhang M, Xu ZQ, Gao CY, Fang CQ, Yan JC, Zhou HD (2011) Vascular risk factors promote conversion from mild cognitive impairment to Alzheimer disease. Neurology 76, 1485-1491.

[25] Raji CA, Ho AJ, Parikshak NN, Becker JT, Lopez OL, Kuller LH, Hua X, Leow AD, Toga AW, Thompson PM (2010) Brain structure and obesity. Hum Brain Mapp 31, 353-364.

[26] Shoelson SE, Herrero L, Naaz A (2007) Obesity, inflammation, and insulin resistance. Gastroenterology 132, 2169-2180.

[27] de Heredia FP, Gómez-Martínez S, Marcos A (2012) Obesity, inflammation and the immune system. Proc Nutr Soc 71, 332-338.

[28] Baker LD, Cross DJ, Minoshima S, Belongia D, Watson GS, Craft S (2011) Insulin resistance and Alzheimer-like reductions in regional cerebral glucose metabolism for cognitively normal adults with prediabetes or early type 2 diabetes. Arch Neurol 68, 51-57.

[29] Korf ESC, White LR, Scheltens P, Launer LJ (2006) Brain aging in very old men with type 2 diabetes: The HonoluluAsia Aging Study. Diabetes Care 29, 2268-2274.

[30] Ronnemaa E, Zethelius B, Sundelof J, Sundstrom J, Degerman-Gunnarsson M, Berne C, Lannfelt L, Kilander L (2008) Impaired insulin secretion increases the risk of Alzheimer disease. Neurology 71, 1065-1071.

[31] Xu WL, von Strauss E, Qiu CX, Winblad B, Fratiglioni L (2009) Uncontrolled diabetes increases the risk of
Alzheimer's disease: A population-based cohort study. Diabetologia 52, 1031-1039.

[32] Talbot K, Wang H-Y, Kazi H, Han L-Y, Bakshi KP, Stucky A, Fuino RL, Kawaguchi KR, Samoyedny AJ, Wilson RS, Arvanitakis Z, Schneider JA, Wolf BA, Bennett DA, Trojanowski JQ, Arnold SE (2012) Demonstrated brain insulin resistance in Alzheimer's disease patients is associated with IGF-1 resistance, IRS-1 dysregulation, and cognitive decline. J Clin Invest 122, 1316-1338.

[33] Bomfim TR, Forny-Germano L, Sathler LB, Brito-Moreira J, Houzel J-C, Decker H, Silverman MA, Kazi H, Melo HM, McClean PL, Holscher C, Arnold SE, Talbot K, Klein WL, Munoz DP, Ferreira ST, De Felice FG (2012) An anti-diabetes agent protects the mouse brain from defective insulin signaling caused by Alzheimer's disease- associated Abeta oligomers. J Clin Invest 122, 1339-1353.

[34] Abbott RD, White LR, Ross GW, Masaki KH, Curb JD, Petrovitch H (2004) Walking and dementia in physically capable elderly men. JAMA 292, 1447-1453.

[35] Karp A, Paillard-Borg S, Wang H-X, Silverstein M, Winblad B, Fratiglioni L (2006) Mental, physical and social components in leisure activities equally contribute to decrease dementia risk. Dement Geriatr Cogn Disord 21, 65-73.

[36] Larson EB, Wang L, Bowen JD, McCormick WC, Teri L, Crane P, Kukull W (2006) Exercise is associated with reduced risk for incident dementia among persons 65 years of age and older. Ann Intern Med 144, 73-81.

[37] Erickson KI, Raji CA, Lopez OL, Becker JT, Rosano C, Newman AB, Gach HM, Thompson PM, Ho AJ, Kuller LH (2010) Physical activity predicts gray matter volume in late adulthood: The Cardiovascular Health Study. Neurology 75, 1415-1422.

[38] Erickson KI, Voss MW, Prakash RS, Basak C, Szabo A, Chaddock L, Kim JS, Heo S, Alves H, White SM, Wojcicki TR, Mailey E, Vieira VJ, Martin SA, Pence BD, Woods JA, McAuley E, Kramer AF (2011) Exercise training increases size of hippocampus and improves memory. Proc Natl Acad Sci U S A 108, 3017-3022.

[39] Buchman AS, Boyle PA, Yu L, Shah RC, Wilson RS, Bennett DA (2012) Total daily physical activity and the risk of AD and cognitive decline in older adults. Neurology 78, 1323-1329.

[40] Middleton LE, Manini TM, Simonsick EM, Harris TB, Barnes DE, Tylavsky F, Brach JS, Everhart JE, Yaffe K (2011) Activity energy expenditure and incident cognitive impairment in older adults. Arch Intern Med 171, 12511257.

[41] Perim Baldo M, Aboussaleh Y, Hardman RJ, Kennedy G, Macpherson H, Scholey AB, Pipingas A (2016) Adherence to a Mediterranean-style diet and effects on cognition in adults: A qualitative evaluation and systematic review of longitudinal and prospective trials. Front Nutr 3, $1-13$.

[42] Morris MC, Brockman J, Schneider JA, Wang Y, Bennett DA, Tangney CC, Rest O, Van De (2016) Association of seafood consumption, brain mercury level, and APOE $\varepsilon 4$ status with brain neuropathology in older adults. JAMA 15, 489-497.

[43] Francis H, Stevenson R (2013) The longer-term impacts of Western diet on human cognition and the brain. Appetite $\mathbf{6 3}$, 119-128.

[44] Crowe M, Andel R, Pedersen NL, Johansson B, Gatz M (2003) Does participation in leisure activities lead to reduced risk of Alzheimer's disease? A prospective study 
of Swedish twins. J Gerontol B Psychol Sci Soc Sci 58, P249-P255.

[45] Andel R, Crowe M, Pedersen NL, Mortimer J, Crimmins E, Johansson B, Gatz M (2005) Complexity of work and risk of Alzheimer's disease: A population-based study of Swedish twins. J Gerontol B Psychol Sci Soc Sci 60, P251-P258.

[46] Stern Y (2012) Cognitive reserve in ageing and Alzheimer's disease. Lancet Neurol 11, 1006-1012.

[47] Sotiropoulos I, Catania C, Pinto LG, Silva R, Pollerberg GE, Takashima A, Sousa N, Almeida OFX (2011) Stress acts cumulatively to precipitate Alzheimer's disease-like tau pathology and cognitive deficits. J Neurosci 31, 7840-7847.

[48] Carroll JC, Iba M, Bangasser DA, Valentino RJ, James MJ, Brunden KR, Lee VM-Y, Trojanowski JQ (2011) Chronic stress exacerbates tau pathology, neurodegeneration, and cognitive performance through a corticotropin-releasing factor receptor-dependent mechanism in a transgenic mouse model of tauopathy. J Neurosci 31, 14436-14449.

[49] Cohen S, Janicki-Deverts D, Doyle WJ, Miller GE, Frank E, Rabin BS, Turner RB (2012) Chronic stress, glucocorticoid receptor resistance, inflammation, and disease risk. Proc Natl Acad Sci U S A 109, 5995-5999.

[50] Chen ST, Siddarth P, Saito NY, Rueda F, Haight T, Ercoli LM, Miller KJ, Lavretsky H, Barrio JR, Bookheimer SY, Small GW, Merrill DA (2014) Psychological well-being and regional brain amyloid and tau in mild cognitive impairment. Am J Geriatr Psychiatry 22, 362-369.

[51] Boyle PA, Buchman A, Wilson R, Yu L, Schneider J, Bennett DA (2012) Effect on purpose of life on the relation between Alzheimer disease pathologic changes on cognitive function in advanced age. Arch Gen Psychiatry 69, 499-505.

[52] Irvine GB, El-Agnaf OM, Shankar GM, Walsh DM (2008) Protein aggregation in the brain: The molecular basis for Alzheimer's and Parkinson's diseases. Mol Med 14, 451564.

[53] Lovestone S, Mcloughlin DM (2002) Protein aggregates and dementia: Is there a common toxicity? J Neurol Neurosurg Psychiatry 72, 152-161.

[54] Campion D, Martinez M, Hannequin D, Brice A, ThomasAnterion C, Michon A, Babron MC, Dubois B, Goas Y, Jaillard-Serradt A, Ledoze F, Pasquier F, Puel M, Zimmerman MA, Bellis M, Mallet J, Agid Y, Clerget-Darpoux F (1995) Characteristics of familial aggregation in early-onset Alzheimer's disease: Evidence of subgroups. Am J Med Genet 60, 221-227.

[55] Sebastiani P, Solovieff N, DeWan AT, Walsh KM, Puca A, Hartley SW, Melista E, Andersen S, Dworkis DA, Wilk JB, Myers RH, Steinberg MH, Montano M, Baldwin CT, Hoh J, Perls TT (2012) Genetic signatures of exceptional longevity in humans. PLoS One 7, e29848.

[56] Harold D, Abraham R, Hollingworth P, Sims R, Gerrish A, Hamshere ML, Pahwa JS, Moskvina V, Dowzell K, Williams A, Jones N, Thomas C, Stretton A, Morgan AR, Lovestone S, Powell J, Proitsi P, Lupton MK, Brayne C, Rubinsztein DC, Gill M, Lawlor B, Lynch A, Morgan K, Brown KS, Passmore PA, Craig D, McGuinness B, Todd S, Holmes C, Mann D, Smith AD, Love S, Kehoe PG, Hardy J, Mead S, Fox N, Rossor M, Collinge J, Maier W, Jessen F, Schürmann B, Heun R, van den Bussche H, Heuser I, Kornhuber J, Wiltfang J, Dichgans M, Frölich L, Hampel H, Hüll M, Rujescu D, Goate AM, Kauwe JSK, Cruchaga C, Nowotny P, Morris JC, Mayo K, Sleegers K, Bettens K, Engelborghs S, De Deyn PP, Van Broeckhoven C, Livingston G, Bass NJ, Gurling H, McQuillin A, Gwilliam R,
Deloukas P, Al-Chalabi A, Shaw CE, Tsolaki M, Singleton AB, Guerreiro R, Mühleisen TW, Nöthen MM, Moebus S, Jöckel K-H, Klopp N, Wichmann H-E, Carrasquillo MM, Pankratz VS, Younkin SG, Holmans PA, O’Donovan M, Owen MJ, Williams J (2009) Genome-wide association study identifies variants at CLU and PICALM associated with Alzheimer's disease. Nat Genet 41, 1088-1093.

[57] Lambert JC, Heath S, Even G, Campion D, Sleegers K, Hiltunen M, Combarros O, Zelenika D, Bullido MJ, Tavernier B, Letenneur L, Bettens K, Berr C, Pasquier F, Fievet N, Barberger-Gateau P, Engelborghs S, De Deyn P, Mateo I, Franck A, Helisalmi S, Porcellini E, Hanon O, de Pancorbo MM, Lendon C, Dufouil C, Jaillard C, Leveillard T, Alvarez V, Bosco P, Mancuso M, Panza F, Nacmias B, Bossu P, Piccardi P, Annoni G, Seripa D, Galimberti D, Hannequin D, Licastro F, Soininen H, Ritchie K, Blanche H, Dartigues JF, Tzourio C, Gut I, Van Broeckhoven C, Alperovitch A, Lathrop M, Amouyel P (2009) Genome-wide association study identifies variants at CLU and CR1 associated with Alzheimer's disease. Nat Genet 41, 1094-1099.

[58] Seshadri S, Fitzpatrick AL, Ikram MA, DeStefano AL, Gudnason V, Boada M, Bis JC, Smith AV, Carassquillo MM, Lambert JC, Harold D, Schrijvers EM, Ramirez-Lorca R, Debette S, Longstreth WT Jr, Janssens AC, Pankratz VS, Dartigues JF, Hollingworth P, Aspelund T, Hernandez I, Beiser A, Kuller LH, Koudstaal PJ, Dickson DW, Tzourio C, Abraham R, Antunez C, Du Y, Rotter JI, Aulchenko YS, Harris TB, Petersen RC, Berr C, Owen MJ, Lopez-Arrieta J, Varadarajan BN, Becker JT, Rivadeneira F, Nalls MA, Graff-Radford NR, Campion D, Auerbach S, Rice K, Hofman A, Jonsson PV, Schmidt H, Lathrop M, Mosley TH, Au R, Psaty BM, Uitterlinden AG, Farrer LA, Lumley T, Ruiz A, Williams J, Amouyel P, Younkin SG, Wolf PA, Launer LJ, Lopez OL, van Duijn CM, Breteler MM, Consortium CHARGE, GERAD1, Consortium, EADI1, Consortium (2010) Genome-wide analysis of genetic loci associated with Alzheimer disease. JAMA 303, 1832-1840.

[59] Jun G, Naj AC, Beecham GW, Wang L-S, Buros J, Gallins PJ, Buxbaum JD, Ertekin-Taner N, Fallin MD, Friedland R, Inzelberg R, Kramer P, Rogaeva E, St George-Hyslop P, Alzheimer's Disease Genetics Consortium, Cantwell LB, Dombroski BA, Saykin AJ, Reiman EM, Bennett DA, Morris JC, Lunetta KL, Martin ER, Montine TJ, Goate AM, Blacker D, Tsuang DW, Beekly D, Cupples LA, Hakonarson H, Kukull W, Foroud TM, Haines J, Mayeux R, Farrer LA, Pericak-Vance MA, Schellenberg GD (2010) Meta-analysis confirms CR1, CLU, and PICALM as alzheimer disease risk loci and reveals interactions with APOE genotypes. Arch Neurol 67, 1473-1484.

[60] Naj AC, Jun G, Beecham GW, Wang L-S, Vardarajan BN, Buros J, Gallins PJ, Buxbaum JD, Jarvik GP, Crane PK, Larson EB, Bird TD, Boeve BF, Graff-Radford NR, De Jager PL, Evans D, Schneider JA, Carrasquillo MM, Ertekin-Taner N, Younkin SG, Cruchaga C, Kauwe JSK, Nowotny P, Kramer P, Hardy J, Huentelman MJ, Myers AJ, Barmada MM, Demirci FY, Baldwin CT, Green RC, Rogaeva E, St George-Hyslop P, Arnold SE, Barber R, Beach T, Bigio EH, Bowen JD, Boxer A, Burke JR, Cairns NJ, Carlson CS, Carney RM, Carroll SL, Chui HC, Clark DG, Corneveaux J, Cotman CW, Cummings JL, DeCarli C, DeKosky ST, Diaz-Arrastia R, Dick M, Dickson DW, Ellis WG, Faber KM, Fallon KB, Farlow MR, Ferris S, Frosch MP, Galasko DR, Ganguli M, Gearing M, Geschwind DH, Ghetti B, Gilbert JR, Gilman S, Giordani B, Glass JD, 
Growdon JH, Hamilton RL, Harrell LE, Head E, Honig LS, Hulette CM, Hyman BT, Jicha GA, Jin L-W, Johnson N, Karlawish J, Karydas A, Kaye JA, Kim R, Koo EH, Kowall NW, Lah JJ, Levey AI, Lieberman AP, Lopez OL, Mack WJ, Marson DC, Martiniuk F, Mash DC, Masliah E, McCormick WC, McCurry SM, McDavid AN, McKee AC, Mesulam M, Miller BL, Miller CA, Miller JW, Parisi JE, Perl DP, Peskind E, Petersen RC, Poon WW, Quinn JF, Rajbhandary RA, Raskind M, Reisberg B, Ringman JM, Roberson ED, Rosenberg RN, Sano M, Schneider LS, Seeley W, Shelanski ML, Slifer MA, Smith CD, Sonnen JA, Spina S, Stern RA, Tanzi RE, Trojanowski JQ, Troncoso JC, Van Deerlin VM, Vinters HV, Vonsattel JP, Weintraub S, Welsh-Bohmer KA, Williamson J, Woltjer RL, Cantwell LB, Dombroski BA, Beekly D, Lunetta KL, Martin ER, Kamboh MI, Saykin AJ, Reiman EM, Bennett DA, Morris JC, Montine TJ, Goate AM, Blacker D, Tsuang DW, Hakonarson H, Kukull WA, Foroud TM, Haines JL, Mayeux R, Pericak-Vance MA, Farrer LA, Schellenberg GD (2011) Common variants at MS4A4/MS4A6E, CD2AP, CD33 and EPHA1 are associated with late-onset Alzheimer's disease. Nat Genet 43, 436-441.

[61] Lee JH, Cheng R, Barral S, Reitz C, Medrano M, Lantigua R, Jiménez-Velazquez IZ, Rogaeva E, St George-Hyslop PH, Mayeux R (2011) Identification of novel loci for Alzheimer disease and replication of CLU, PICALM, and BIN1 in Caribbean Hispanic individuals. Arch Neurol 68, 320-328.

[62] Logue MW, Schu M, Vardarajan BN, Buros J, Green RC, Go RCP, Griffith P, Obisesan TO, Shatz R, Borenstein A, Cupples LA, Lunetta KL, Fallin MD, Baldwin CT, Farrer LA (2011) A comprehensive genetic association study of Alzheimer disease in African Americans. Arch Neurol 68, 1569-1579.

[63] Lambert JC, Ibrahim-Verbaas CA, Harold D, Naj AC, Sims $\mathrm{R}$, Bellenguez C, DeStafano AL, Bis JC, Beecham GW, Grenier-Boley B, Russo G, Thorton-Wells TA, Jones N, Smith AV, Chouraki V, Thomas C, Ikram MA, Zelenika D, Vardarajan BN, Kamatani Y, Lin CF, Gerrish A, Schmidt H, Kunkle B, Dunstan ML, Ruiz A, Bihoreau MT, Choi SH, Reitz C, Pasquier F, Cruchaga C, Craig D, Amin N, Berr C, Lopez OL, De Jager PL, Deramecourt V, Johnston JA, Evans D, Lovestone S, Letenneur L, Morón FJ, Rubinsztein DC, Eiriksdottir G, Sleegers K, Goate AM, Fiévet N, Huentelman MW, Gill M, Brown K, Kamboh MI, Keller L, Barberger-Gateau P, McGuiness B, Larson EB, Green R, Myers AJ, Dufouil C, Todd S, Wallon D, Love S, Rogaeva E, Gallacher J, St George-Hyslop P, Clarimon J, Lleo A, Bayer A, Tsuang DW, Yu L, Tsolaki M, Bossú P, Spalletta G, Proitsi P, Collinge J, Sorbi S, Sanchez-Garcia F, Fox NC, Hardy J, Deniz Naranjo MC, Bosco P, Clarke R, Brayne C, Galimberti D, Mancuso M, Matthews F, Moebus S, Mecocci P, Del Zompo M, Maier W, Hampel H, Pilotto A, Bullido M, Panza F, Caffarra P, Nacmias B, Gilbert JR, Mayhaus M, Lannefelt L, Hakonarson H, Pichler S, Carrasquillo MM, Ingelsson M, Beekly D, Alvarez V, Zou F, Valladares O, Younkin SG, Coto E, Hamilton-Nelson KL, Gu W, Razquin C, Pastor P, Mateo I, Owen MJ, Faber KM, Jonsson PV, Combarros O, O'Donovan MC, Cantwell LB, Soininen H, Blacker D, Mead S, Mosley TH, Bennett DA, Harris TB, Fratiglioni L, Holmes C, de Bruijn RF, Passmore P, Montine TJ, Bettens K, Rotter JI, Brice A, Morgan K, Foroud TM, Kukull WA, Hannequin D, Powell JF, Nalls MA, Ritchie K, Lunetta KL, Kauwe JS, Boerwinkle E, Riemenschneider M, Boada M, Hiltuenen M, Martin ER, Schmidt R, Rujescu D, Wang LS, Dartigues JF, Mayeux R, Tzourio C, Hofman
A, Nöthen MM, Graff C, Psaty BM, Jones L, Haines JL, Holmans PA, Lathrop M, Pericak-Vance MA, Launer LJ, Farrer LA, van Duijn CM, Van Broeckhoven C, Moskvina V, Seshadri S, Williams J, Schellenberg GD, Amouyel P (2013) Meta-analysis of 74,046 individuals identifies 11 new susceptibility loci for Alzheimer's disease. Nat Genet 45, 1452-1458.

[64] Karch C, Goate A (2015) Alzheimer's disease risk genes and mechanisms of disease. Biol Psychiatry 77, 43-51.

[65] Jonsson T, Atwal JK, Steinberg S, Snaedal J, Jonsson PV, Bjornsson S, Stefansson H, Sulem P, Gudbjartsson D, Maloney J, Hoyte K, Gustafson A, Liu Y, Lu Y, Bhangale T, Graham RR, Huttenlocher J, Bjornsdottir G, Andreassen OA, Jönsson EG, Palotie A, Behrens TW, Magnusson OT, Kong A, Thorsteinsdottir U, Watts RJ, Stefansson K (2012) A mutation in APP protects against Alzheimer's disease and age-related cognitive decline. Nature 488, 96-99.

[66] Wang B, Yang W, Wen W, Sun J, Su B, Liu B, Ma D, Lv D, Wen Y, Qu T, Chen M, Sun M, Shen Y, Zhang X (2010) $\gamma$-secretase gene mutations in familial acne inversa. Science 330, 1065.

[67] Lee JH, Yu WH, Kumar A, Lee S, Mohan PS, Peterhoff CM, Wolfe DM, Martinez-Vicente M, Massey AC, Sovak G, Uchiyama Y, Westaway D, Cuervo AM, Nixon RA (2010) Lysosomal proteolysis and autophagy require presenilin 1 and are disrupted by Alzheimer-related PS1 mutations. Cell 141, 1146-1158.

[68] Neely KM, Green KN, LaFerla FM (2011) Presenilin is necessary for efficient proteolysis through the autophagylysosome system in a $\gamma$-secretase-independent manner. J Neurosci 31, 2781-2791.

[69] Cruchaga C, Chakraverty S, Mayo K, Vallania FLM, Mitra RD, Faber K, Williamson J, Bird T, Diaz-Arrastia R, Foroud TM, Boeve BF, Graff-Radford NR, Jean St, Lawson P, Ehm M, Mayeux MG, Goate R, for the AM, - NIA-LOAD, Family Study NCRAD, Consortium (2012) Rare variants in APP, PSEN1 and PSEN2 increase risk for AD in late-onset Alzheimer's disease families. PLoS One 7, 1-10.

[70] Li H, Wang B, Wang Z, Guo Q, Tabuchi K, Hammer RE, Südhof TC, Zheng H (2010) Soluble amyloid precursor protein (APP) regulates transthyretin and Klotho gene expression without rescuing the essential function of APP. Proc Natl Acad Sci U S A 107, 17362-17367.

[71] Sparks DL (1997) Coronary artery disease, hypertension, ApoE, and cholesterol: A link to Alzheimer's disease? Ann NY Acad Sci 826, 128-146.

[72] Puglielli L, Tanzi RE, Kovacs DM (2003) Alzheimer's disease: The cholesterol connection. Nat Neurosci 6, 345-351.

[73] Morris JC, Roe CM, Xiong C, Fagan AM, Goate AM, Holtzman DM, Mintun MA (2010) APOE predicts amyloidbeta but not tau Alzheimer pathology in cognitively normal aging. Ann Neurol 67, 122-131.

[74] Castellano JM, Kim J, Stewart FR, Jiang H, DeMattos RB, Patterson BW, Fagan AM, Morris JC, Mawuenyega KG, Cruchaga C, Goate AM, Bales KR, Paul SM, Bateman RJ, Holtzman DM (2011) Human apoE isoforms differentially regulate brain amyloid- $\beta$ peptide clearance. Sci Transl Med 3, 89ra57.

[75] Kim J, Jiang H, Park S, Eltorai AEM, Stewart FR, Yoon H, Basak JM, Finn MB, Holtzman DM (2011) Haploinsufficiency of human APOE reduces amyloid deposition in a mouse model of amyloid- $\beta$ amyloidosis. J Neurosci 31, 18007-18012. 
[76] Roses AD, Lutz MW, Amrine-Madsen H, Saunders AM, Crenshaw DG, Sundseth SS, Huentelman MJ, Welsh-Bohmer KA, Reiman EM (2010) A TOMM40 variable-length polymorphism predicts the age of late-onset Alzheimer's disease. Pharmacogenomics J 10, 375-384.

[77] Head D, Bugg JM, Goate AM, Fagan AM, Mintun MA, Benzinger T, Holtzman DM, Morris JC (2012) Exercise engagement as a moderator of the effects of APOE genotype on amyloid deposition. Arch Neurol 69, 636-643.

[78] Lewis TL, Cao D, Lu H, Mans RA, Su YR, Jungbauer L, Linton MF, Fazio S, LaDu MJ, Li L (2010) Overexpression of human apolipoprotein A-I preserves cognitive function and attenuates neuroinflammation and cerebral amyloid angiopathy in a mouse model of Alzheimer disease. J Biol Chem 285, 36958-36968.

[79] Braskie MN, Jahanshad N, Stein JL, Barysheva M, McMahon KL, de Zubicaray GI, Martin NG, Wright MJ, Ringman JM, Toga AW, Thompson PM (2011) Common Alzheimer's disease risk variant within the CLU gene affects white matter microstructure in young adults. $J$ Neurosci 31, 6764-6770.

[80] Lipinski MM, Zheng B, Lu T, Yan Z, Py BF, Ng A, Xavier RJ, Li C, Yankner BA, Scherzer CR, Yuan J (2010) Genomewide analysis reveals mechanisms modulating autophagy in normal brain aging and in Alzheimer's disease. Proc Natl Acad Sci U S A 107, 14164-14169.

[81] Griciuc A, Serrano-Pozo A, Parrado AR, Lesinski AN, Asselin CN, Mullin K, Hooli B, Choi S, Hyman BT, Tanzi RE (2013) Alzheimer's disease risk gene cd33 inhibits microglial uptake of amyloid beta. Neuron 78, 631-643.

[82] Guerreiro R, Wojtas A, Bras J, Carrasquillo M, Rogaeva E, Majounie E, Cruchaga C, Sassi C, Kauwe JSK, Younkin S, Hazrati L, Collinge J, Pocock J, Lashley T, Williams J, Lambert J-C, Amouyel P, Goate A, Rademakers R, Morgan K, Powell J, St George-Hyslop P, Singleton A, Hardy J (2013) TREM2 Variants in Alzheimer's Disease. $N$ Engl $J$ Med 368, 117-127.

[83] Jonsson T, Stefansson H, Steinberg S, Jonsdottir I, Jonsson PV, Snaedal J, Bjornsson S, Huttenlocher J, Levey AI, Lah JJ, Rujescu D, Hampel H, Giegling I, Andreassen OA, Engedal K, Ulstein I, Djurovic S, Ibrahim-Verbaas C, Hofman A, Ikram MA, van Duijn CM, Thorsteinsdottir U, Kong A, Stefansson K (2013) Variant of TREM2 Associated with the Risk of Alzheimer's Disease. N Engl J Med 368, 107-116.

[84] Bhaskar K, Konerth M, Kokiko-Cochran ON, Cardona A, Ransohoff RM, Lamb BT (2010) Regulation of tau pathology by the microglial fractalkine receptor. Neuron 68, 19-31.

[85] Adlard PA, Parncutt JM, Finkelstein DI, Bush AI (2010) Cognitive loss in zinc transporter-3 knock-out mice: A phenocopy for the synaptic and memory deficits of Alzheimer's disease? J Neurosci 30, 1631-1636.

[86] Shema R, Haramati S, Ron S, Hazvi S, Chen A, Sacktor TC, Dudai Y (2011) Enhancement of consolidated longterm memory by overexpression of protein kinase Mzeta in the neocortex: Supplementary Material. Science 331, 12071210.

[87] Zhang Y, Kurup P, Xu J, Carty N, Fernandez SM, Nygaard HB, Pittenger C, Greengard P, Strittmatter SM, Nairn AC, Lombroso PJ (2010) Genetic reduction of striatal-enriched tyrosine phosphatase (STEP) reverses cognitive and cellular deficits in an Alzheimer's disease mouse model. Proc Natl Acad Sci U S A 107, 19014-19019.
[88] Nunez-Iglesias J, Liu CC, Morgan TE, Finch CE, Zhou XJ (2010) Joint genome-wide profiling of miRNA and mRNA expression in Alzheimer's disease cortex reveals altered miRNA regulation. PLoS One 5, e8898.

[89] Rao JS, Keleshian VL, Klein S, Rapoport SI (2012) Epigenetic modifications in frontal cortex from Alzheimer's disease and bipolar disorder patients. Transl Psychiatry 2, e132.

[90] Gräff J, Rei D, Guan J-S, Wang W-Y, Seo J, Hennig KM, Nieland TJF, Fass DM, Kao PF, Kahn M, Su SC, Samiei A, Joseph N, Haggarty SJ, Delalle I, Tsai L-H (2012) An epigenetic blockade of cognitive functions in the neurodegenerating brain. Nature 483, 222-226.

[91] De Jager PL, Srivastava G, Lunnon K, Burgess J, Schalkwyk LC, Yu L, Eaton ML, Keenan BT, Ernst J, McCabe C, Tang A, Raj T, Replogle J, Brodeur W, Gabriel S, Chai HS, Younkin C, Younkin SG, Zou F, Szyf M, Epstein CB, Schneider JA, Bernstein BE, Meissner A, ErtekinTaner N, Chibnik LB, Kellis M, Mill J, Bennett DA (2014) Alzheimer's disease: Early alterations in brain DNA methylation at ANK1, BIN1, RHBDF2 and other loci. Nat Neurosci 17, 1156-1163.

[92] Lord J, Cruchaga C (2014) The epigenetic landscape of Alzheimer's disease. Nat Neurosci 17, 1138-1140.

[93] Lunnon K, Smith R, Hannon E, De Jager PL, Srivastava G, Volta M, Troakes C, Al-Sarraj S, Burrage J, Macdonald R, Condliffe D, Harries LW, Katsel P, Haroutunian V, Kaminsky Z, Joachim C, Powell J, Lovestone S, Bennett DA, Schalkwyk LC, Mill J (2014) Methylomic profiling implicates cortical deregulation of ANK1 in Alzheimer's disease. Nat Neurosci 17, 1164-1170.

[94] Yu L, Chibnik LB, Srivastava GP, Pochet N, Yang J, Xu J, Kozubek J, Obholzer N, Leurgans SE, Schneider JA, Meissner A, De Jager PL, Bennett DA (2015) Association of brain DNA methylation in SORL1, ABCA7, HLADRB5, SLC24A4, and BIN1 with pathological diagnosis of Alzheimer disease. JAMA Neurol 72, 15-24.

[95] Zhang B, Gaiteri C, Bodea LG, Wang Z, McElwee J, Podtelezhnikov AA, Zhang C, Xie T, Tran L, Dobrin R, Fluder E, Clurman B, Melquist S, Narayanan M, Suver C, Shah H, Mahajan M, Gillis T, Mysore J, MacDonald ME, Lamb JR, Bennett DA, Molony C, Stone DJ, Gudnason V, Myers AJ, Schadt EE, Neumann H, Zhu J, Emilsson V (2013) Integrated systems approach identifies genetic nodes and networks in late-onset Alzheimer's disease. Cell 153, 707-720.

[96] Raj T, Rothamel K, Mostafavi S, Ye C, Lee MN, Replogle JM, Feng T, Lee M, Asinovski N, Frohlich I, Imboywa S, Von Korff A, Okada Y, Patsopoulos NA, Davis S, McCabe C, Paik H, Srivastava GP, Raychaudhuri S, Hafler DA, Koller D, Regev A, Hacohen N, Mathis D, Benoist C, Stranger BE, De Jager PL (2014) Polarization of the effects of autoimmune and neurodegenerative risk alleles in leukocytes. Science 344, 519-523.

[97] Colantuoni C, Lipska BK, Ye T, Hyde TM, Tao R, Leek JT, Colantuoni EA, Elkahloun AG, Herman MM, Weinberger DR, Kleinman JE (2011) Temporal dynamics and genetic control of transcription in the human prefrontal cortex. Nature 478, 519-523. 